\title{
The Governance of the IMF: The Need for Comprehensive Reform*
}

\author{
Daniel D. Bradlow"*
}

${ }^{*}$ Paper prepared for the Meeting of the G24 Technical Committee, Singapore, September 2006

${ }^{* *}$ Professor of Law and Director, International Legal Studies Program, American University, Washington College of Law, Washington D.C. and Research Associate, Centre for Human Rights, Faculty of Law, University of Pretoria, Tel: (202)274-4205, email: bradlow@wcl.american.edu 


\title{
The Governance of the IMF: The Need for Comprehensive Reform ${ }^{1}$
}

\author{
Daniel D. Bradlow ${ }^{2}$
}

I. Introduction

This paper focuses on the governance of the International Monetary Fund (IMF) ${ }^{3}$. It argues that the IMF's current governance arrangements are characterized by non-responsiveness to the concerns of key stakeholders in the IMF, lack of accountability, non-representative decision-making, lack of transparency, and poorly defined relations with other international organizations.

It further contends that the basic cause of the IMF's current problems is its failure to adequately adapt its decision-making arrangements and operating practices to the changes that have occurred in the nature and scope of its operations over the past 30 years as it has slowly mutated from a monetary organization into a macro-economically oriented development

\footnotetext{
${ }^{1}$ Paper prepared for the Meeting of the G24 Technical Committee, Singapore, September 2006. The author wishes to thank Elizabeth Canty and Alexandra Huber for their research assistance.

${ }^{2}$ Professor of Law and Director, International Legal Studies Program, American University, Washington College of Law, Washington D.C. and Research Associate, Centre for Human Rights, Faculty of Law, University of Pretoria, Tel: (202)274-4205, email: bradlow@wcl.american.edu .

${ }^{3}$ There is an extensive literature, from many different political perspectives on the many policy and program problems with the IMF. See, for example, See generally Joseph E. Stiglitz, GLOBALIZATION AND ITS DisCONTENTS (W.W. Norton \& Company, 2002); Paul Blustein, THE CHASTENING: INSIDE THE CRISIS THAT ROCKED THE GLOBAL FINANCIAL SYSTEM AND HUMBLED THE IMF (PublicAffairs, 2001) (exploring the Asian financial crisis of 1997 and the IMF's role in that crisis); Paul Blustein, AND THE MONEY KEPT ROLLING IN (AND OUT) (PublicAffairs, 2005) (looking at the interconnectedness and causal relationships among Wall Street, the IMF, and Argentina's bankruptcy in 2001). INTERNATIONAL MONETARY FUND, EXTERNAL EVALUATION OF IMF SURVEILLANCE (1999), at http://www.imf.org/external/pubs/ft/extev/surv/eval.pdf [hereinafter EVALUATION OF SURVEILLANCE]; EXTERNAL EVALUATION OF THE ESAF, Report by a Group of Independent Experts (June 1998), at http://www.imf.org/external/pubs/ft/extev/index.htm [hereinafter EXTERNAL EVALUATION ON ESAF]; Jeffrey D. Sachs, The IMF and the Asian Flu, THE AMERICAN ProsPeCt, Mar.-Apr. 1998, at 16-21; Anna J. Schwartz, Time to Terminate the ESF and the IMF, FOREIGN POLICY Briefing No. 48, Washington, D.C.: Cato Institute (Aug. 26, 1998); Martin Feldstein, Refocusing the IMF, ForEIGN AFFAIRS 77(2), at 20-33 (1998); MELTZER COMMISSION, REPORT OF THE INTERNATIONAL FINANCIAL INSTITUTION ADVISORY COMMISSION (2000); J.M. Griesgraber and B. Gunther, THE WORLD’s MONETARY SySTEM (1996); FIFTY YEARs Is ENOUgh: THE CASE AGAINST THE WORLD BANK AND THE INTERNATIONAL MONETARY FUND, (Kevin Danaher, ed., 1994).
} 
financing institution. Its attempt to squeeze its new functions and relations into its old structures has resulted in distortions in the IMF's relations with its member states and their citizens and with other international organizations, and in its internal governance arrangements.

The problems caused by these distortions are now coming to a head. The reason is that, while the ability of the IMF to provide satisfactory services to its developing country member states has been widely challenged for at least 2 decades, it's ability to effectively manage the international monetary system , to respond to the interests of the rising new economic powers, and to deal with the financial and monetary issues of most interest to the rich countries is now also being questioned by leading officials in its most powerful member states. ${ }^{4}$

It follows from this analysis that the current governance reform proposals of the IMF Managing Director ${ }^{5}$ - to increase the votes of certain particularly under-represented member states, and to significantly increase the basic votes for all member states—are an inadequate response to the IMF's problems. Even if implemented, they will only address one dimension of the problem.

In order to establish this thesis, the paper is divided into a number of sections. The next

\footnotetext{
${ }^{4}$ See, for example, Timothy D. Adams, “'The IMF: Back to Basics”, in REFORMING THE IMF FOR THE $21^{\text {st }}$ CENTURY, Edwin M. Truman (ed) ( 2006); King, Mervyn, Reform of the International Monetary Fund, at 2 (speech given at the Indian Council for Research on International Economic Relations in New Delhi, India) (Feb. 20, 2006) (warning that the IMF could slip into obscurity); Dodge, David, The Evolving Monetary Order and the Need for an Evolving IMF, Lecture to the Woodrow Wilson School of Public Affairs, Princeton, March 30, 2006, available at www.bankofcanada.ca/en/speeches/2006/sp06-6.html (arguing for reforms in the IMF's functions and governance so that it can more effectively fulfill its role in the global economy) see also Interview with Lorenzo Bini Smaghi, “Eurozone 'Needs Bigger IMF Role” , Financial Times (London), March 29, 2006 (stating that the IMF "risks becoming a 'mere secretariat' for international policymakers").(Timothy Adams is the Under-Secretary for International Affairs in the U.S. Treasury, Mervyn King is the governor of the Bank of England, David Dodge is the Governor of the Bank of Canada and Lorenzo Bini Smaghi is a European Central Bank executive board member).

${ }^{5}$ IMF, The Managing Director's Report on the Funds Medium-Term Strategy (September 15, 2006), at http://www.imf.org/external/np/omd/2005/eng/091505.pdf; IMF, The Managing Director's Report on Implementing the Fund's Medium Term Strategy (April 5, 2006), at http://www.imf.org/external/np/pp/eng/2006/040506.pdf. Rodrigo De Rato, Progress in Implementing the Fund's Medium-Term Strategy (speech given at the Foreign Correspondent's Club in Tokyo, Japan) (August 3, 2006), available at http://www.imf.org/external/np/speeches/2006/080306.htm.
} 
section briefly discusses some key points of the IMF's original governance arrangements and of the impact of the evolution in its operations over the past three decades on its institutional arrangements. Section III describes 5 distortions that have arisen from the combination of the evolution in the IMF's functions and the inflexibility of its decision making structures. Section IV briefly reviews the key governance problems that have resulted from these five distortions. Section V contains a detailed proposal for a comprehensive governance reform program for the IMF.

\section{The IMF's Original Governance Arrangements and the Evolution in Its Operations}

At the Bretton Woods Conference in 1944, the 44 participating countries, agreed to surrender some of their monetary sovereignty to the IMF in exchange for the benefits of a rulesbased monetary system ${ }^{6}$. The participants created the IMF to oversee the system. Its primary function was to ensure that members were following policies that were consistent with the maintenance of the par value they had established for their currency. To encourage compliance with these obligations and as part of the benefits of membership, the IMF provided financial support to any member state experiencing serious balance of payments difficulties ${ }^{7}$.

The operating practices and governance arrangements for the IMF were designed to support these original regulatory and financing functions. Some of their features deserve mention because of their relevance to the IMF's current governance problems.

First, the annual surveillance missions that the IMF conducted in each member state, pursuant to Article IV of its Articles of Agreement, focused on those macroeconomic variables that influenced the ability of the country to maintain the par value of its currency. ${ }^{8}$ Given the

\footnotetext{
${ }^{6}$ See Margaret Garritsen de Vries, THE IMF IN A CHANGING WORLD 1945-1985 14-20 (1986).

${ }^{7}$ See, International Monetary Fund, Articles of Agreement art. I (1944) (stating purposes of IMF) [hereinafter IMF Articles].

${ }^{8}$ See Garritsen, supra note 5; RoBert A. Blecker, TAMING GlOBAL FInANCE 1-7 (1999); Daniel D. Bradlow, The World Bank, the IMF, and Human Rights, 6 TRANSNAT'L L. \& CONTEMP. PROBS. 47, 6869 (1996).
} 
nature of its interest, it made sense for the member states to stipulate in the Articles of Agreement, that the IMF should limit its interactions with the member state to its Central Bank and Ministry of Finance ${ }^{9}$.

Second, maintenance of the par value system also placed limits on the conditions the IMF would attach to the financing it offered its member countries. These conditions focused on those macro-economic and monetary issues that were relevant to the restoration of a sustainable balance of payments and par value for the currency. The nature of these conditions placed some limits on the IMF's intrusion into the policy-making process of its member states because it left the recipient state free to choose the specific policy measures for meeting these conditions.

It should be noted that the sensitivity of a change in the par value of a currency led the IMF to seek to keep the substance of the standby arrangements, particularly the Letter of Intent, confidential. Consequently, it developed a formalistic interpretation of the legal nature of a standby arrangement, which denied that the relationship was contractual. This avoided both the obligation to treat the arrangements, as an international agreement that, pursuant to the United Nations Charter, must be made public ${ }^{10}$ and the vexing issue of potential liability that could result from states failing to comply with the terms of the standby arrangement ${ }^{11}$.

Third, since the IMF was designed to be a monetary and not a development institution, it did not formally distinguish between its member states on the basis of their wealth or level of development. Its justifications for this approach were that since all states were participants in the same monetary system, that the ability of each state to maintain its par value was influenced by the same variables, and that they were all vulnerable to the same types of balance of payments problems, they should all be treated in a "uniform” manner. This approach resulted in the IMF offering all member states access to its financing facilities on the same terms and conditions. Similarly, the IMF's annual consultations with each member state covered essentially the same

\footnotetext{
${ }^{9}$ See IMF ARTICLES, supra note 6, at art. V, § 1.

${ }^{10}$ See U.N. CHARTER art. 102 (1945).

${ }^{11}$ See Joseph Gold, The legal character of the Fund's stand-by arrangements and why it matters, IMF (1980).
} 
issues. The IMF concretized this approach by adopting a principle of uniformity as one of its key operating principles ${ }^{12}$. The principle made sense during the period of the par value system when many of the rich countries, including the United States, in fact, did make use of the IMF's financing services ${ }^{13}$.

Fourth, the IMF's original governance structure contained some checks on the power of the richest member states, even though the IMF's system of weighted voting gave these countries the greatest influence in the IMF. Since the richest and most powerful states could anticipate having to use the financing services of the IMF, they were unlikely to advocate policies that were unduly burdensome for those states that did use the IMF's services ${ }^{14}$. They understood that the policies they supported in the IMF could one day directly affect their own citizens and they could be held accountable for them.

Fifth, the governance structure was also build around the expectation that the IMF's Board of Executive Directors, acting on behalf of the membership, would exercise firm control over the IMF's management and staff. ${ }^{15}$ During the period of the par value system, this expectation was realistic because the number of IMF programs was relatively small, the scope of the programs was limited, and the Board was reasonably representative of the IMF membership — the original 39 member states were represented by 12 Executive Directors.

\footnotetext{
${ }^{12}$ See Joseph Gold, Legal and Institutional Aspects of the Int'l Monetary System: Selected Essays I, at 469-519 (1979) [hereinafter Gold I].

${ }^{13}$ See Joseph Gold, Legal and Institutional Aspects of the Int'l Monetary System: Selected Essays II, at 647-650 (1984) [hereinafter Gold II]; Bradlow, supra note 8.

${ }^{14}$ A good example of this point is that the IMF originally adopted the view that the standby arrangement is not a contract under the influence of the industrialized countries. These countries, who at the time were still using the financing facilities of the IMF, did not wish to have their policy making options constrained by a publicly available agreement with the IMF. They also did not wish to be seen as breaching their obligations if they failed to affect the policies set out in the Letter of Intent that would form part of their standby arrangement with the IMF. See JOSEPH GOLD, INTERPRETATION: THE IMF AND INTERNATIONAL LAW 371 n.125 (1996).

${ }^{15}$ When the IMF was established, John Maynard Keynes had argued for a part-time Board that was less actively involved in the day-to-day affairs of the IMF. However, he lost this argument and the Board became a full time Board that plays an active role in the operations of the IMF. Skidelsky, Robert. JoHN MAYNARD KEYNES: FightiNG FOR FREEDOM 1937-1946. Vol. 3. (Viking, 2000). This suggestion has recently been revived by the Governor of the Bank of England. See King, supra note 5.
} 
After the collapse of the par value system, which was formalized with the adoption of the Second Amendment to the IMF's Articles of Agreement in 1978, the IMF lost its well-defined monetary mission ${ }^{16}$. If a member state was not expected to maintain any particular value for its currency and could choose its own exchange rate policy, then what was the IMF supposed to be monitoring in its annual consultations with the country?

The amended Article IV provides only limited guidance. It requires each member state to “endeavour to direct its economic and financial policies toward...fostering orderly economic growth...”; to "seek to promote stability by fostering orderly underlying economic and financial conditions"; and to "follow exchange rate policies compatible with the undertakings" of Article IV. ${ }^{17}$ The lack of specificity of this language suggests, as in fact has become the case, that the IMF needs to look at any aspect of the member state’s economic and financial policies and policy making arrangements that could affect its “orderly economic growth”, its external balance of payments and the value of its currency. ${ }^{18}$ In other words, the Second Amendment has resulted in the IMF dramatically expanding the scope of its Article IV consultations. ${ }^{19}$ It has also led to an expansion in the range of conditions that the IMF attaches to its financing. ${ }^{20}$

The Second Amendment had disparate impacts on different groups of IMF member states. In fact, for most of the period since the Second Amendment, IMF member states could be

\footnotetext{
${ }^{16}$ See IMF ARTICLES OF AGREEMENT, amend. I (1978), at http://www.imf.org/external/pubs/ft/aa/index.htm; GoLD II, supra note 9, at 108-113.

${ }^{17}$ See IMF ARTICLES, supra note 6, at art. IV, § 1 (adopted July 22, 1944, entered into force 1945, amended effective April 1, 1978).

${ }^{18}$ In recent years, as the process of globalization has intensified, the IMF has been forced to expand its surveillance beyond a national focus to include regional and even global considerations. See de Rato, Rodrigo. “The IMF’s Medium-Term Strategy: New Priorities, New Directions,” pp. 1, 3. Feb. 9, 2006; de Rato, Rodrigo. "New Priorities for an Era of Globalisation,” p. 3. Jan. 2, 2006; IMF. "The Managing Director's Report on the Fund's Medium-Term Strategy,” pp. 4-6. Sept. 15, 2005.

${ }^{19}$ See Gold I, supra note 10, at 573-4.

${ }^{20}$ The IMF's financial arrangements with Russia and Indonesia contained over 100 conditions each. These conditions dealt with most of the issues cited in the text. In the case of the HIPC countries, the IMF requires them to follow participatory processes in developing their Poverty Reduction Strategy Papers and to allocate certain portions of their savings from debt reduction to primary health and education budgets. For more information see IMF website <www.imf.org>.
} 
classified into two groups. The first group, which can be called "IMF supplier states", consists of those countries which, because of their wealth, their access to alternate sources of funds and for political reasons, have no intention of using the IMF's services in the foreseeable future ${ }^{21}$. These countries do not need to pay particular attention to the views of the $\mathrm{IMF}^{22 .}$ For these countries, the most important of which are the G-7 countries, the Second Amendment meant that they regained their monetary sovereignty from the IMF and escaped from its control.

The second group, which consists of those member states that need or know they may need IMF financing in the foreseeable future can be called the "IMF consumer" countries. These states must pay careful attention to the views of the IMF because they will influence the conditions that the IMF will attach to the funds it provides the state. The IMF can also influence these countries' access to other sources of funds.

In recent years, a third group of states has emerged. This group consists of those countries that have good access to private financial markets and have accumulated sufficiently large reserves that they can effectively "self-insure” against the risk of payments and capital account crises. ${ }^{23}$ The states in this group, like the IMF supplier states, appear to be in the process of "buying” their independence from the IMF. In fact, it can be argued that a key motivation for the Managing Director's current governance reform proposal is to give this emerging third group

\footnotetext{
${ }^{21}$ None of these countries have used the financial resources of the Fund since 1978. See DE VRIES, supra note 6, at 119 (noting that during 1972 to 1978, the IMF approved stand-by arrangements for Italy and the United Kingdom).

${ }^{22}$ Despite this, the IMF continues to devote considerable amount of resources to its surveillance of these countries. See EVAluATION OF SURVEILLANCE, supra note 4.

${ }^{23}$ For example, China’s gross official reserves were projected at $\$ 829$ billion for 2005 , India's reserves were projected at $\$ 139.5$ billion for 2005/2006, and Korea's reserves are projected by IMF staff to be at $\$ 3.9$ billion for 2005. See IMF Executive Board Article IV Consultation Reports for data on each country, available at http://www.imf.org. Andrew Ball and Richard McGregor. G20 Calls for Reform of IMF and World Bank. FiNANCIAL TIMES, Oct. 16, 2005; G20, The G20 Statement on Reforming the Bretton Woods Institutions (calling for improvement in governance, strategy, and operations of both the IMF and the World Bank). For an interesting discussion of the significance of the size of the reserves, see Lawrence H. Summers, Reflections on Global Account Imbalances and Emerging Market Reserve Accumulation, L.K.Jha Memorial Lecture, Reserve Bank of India, March 24, 2006, available at www.president.harvard.edu/speeches/2006/0324_rbi.html (showing that reserves of emerging market Asian and oil exporting countries exceed short term debt due within one year by about $\$ 2$ trillion and growing each year by several hundred million dollars)
} 
of states an incentive to remain actively engaged with the IMF. ${ }^{24}$

\section{Institutional Implications of the Changing Role of the IMF: The Five Distortions}

Since the adoption of the Second Amendment in 1978, the IMF has attempted to implement its expanding range of activities without making any significant changes in its governance arrangements. This means that the IMF has "forced" its new broader functions into its existing decision-making structures and governance arrangements and its existing interpretation of its mandate. This has resulted in five distortions that are undermining the effectiveness of its operations, are increasing hostility to the IMF around the world, and are raising questions about its relevance.

These five distortions are:

a) The IMF's relations with the industrialized countries, in particular the G-7;

b) The IMF's relations with developing countries that utilize or expect to utilize its financial services;

c) The IMF's relations with the citizens of its member countries;

d) The IMF's relations with other international organizations; and

e) Three legal issues.

Each of these problem areas is discussed in more detail below.

\section{A. Relations Between the IMF and The Industrial Countries}

Since the adoption of the Second Amendment, the industrial countries, in fact, have relied on their own resources and the private financial markets to meet their financial needs. They have not made use of the resources of the IMF. They have in effect concluded that the IMF is not a politically or economically feasible source of funds for them.

\footnotetext{
${ }^{24}$ See, supra notes 4 and 5. See also Peter Costello, The Global Monetary Fund Needs to Reform Its Quotas, FinANCIAL Times, Aug. 21, 2006 at 9.
} 
The fact that these countries do not intend using the IMF's financing facilities has freed them from any need to defer to any advice the IMF may offer them in their annual consultations. In other words, they have regained the sovereignty that they surrendered to the IMF at the Bretton Woods Conference in 1944.

This does not, however, mean that they have regained full monetary sovereignty. The world's economy has become too integrated for that. Instead these countries, particularly the G-7 have used an alternate set of international fora to resolve all monetary and financial issues that may arise between them. These fora include the G-7, the Organization of Economic Cooperation and Development (OECD), the Basel Committee of Bank Regulators, and the International Organization of Securities Commissions (IOSCO).

When these are not deemed adequate, the G-7 have been willing to create additional fora. For example, after the Asian financial crisis and the near bankruptcy of Long Term Capital Management in 1998, the G-7 became concerned about the regulatory framework for the international financial markets. These countries decided that they needed a mechanism through which they could coordinate national regulation of financial markets and financial institutions. Consequently, they created the Financial Stability Forum ${ }^{25}$ in which the regulators of the banking, securities and insurance industries of major industrial countries and financial centers meet together with representatives of the IMF, the World Bank and the BIS to discuss regulatory issues of mutual concern. They also created the G-2026, which consists of the G-7 plus some

\footnotetext{
${ }^{25}$ For information on the Financial Stability Forum, see http://www.fsforum.org ("The Financial Stability Forum (FSF) was convened in April 1999 to promote international financial stability through information exchange and international co-operation in financial supervision and surveillance. The Forum brings together . . . national authorities responsible for financial stability in significant international financial centers, international financial institutions, sector-specific international groupings of regulators and supervisors, and committees of central bank experts.”). The members of the FSF are: Australia, Canada, France, Germany, Hong Kong, Italy, Japan, Netherlands, Singapore, United Kingdom, and the United States.

${ }^{26}$ For information on the G-20, see http://www.g20.org/indexe.html (describing the G-20 as an informal mechanism for dialogue among systemically important countries within the framework of the Bretton Woods institutional system). "The G-20 promotes discussion, and studies and reviews policy issues
} 
other key industrial and emerging market countries.

Since the industrialized countries have no intention of using the IMF, it is reasonable to question why the G-7 have continued to support the IMF. The reason is that they find its influence over poor and middle income countries undergoing transformations or experiencing serious macro-economic and monetary problems useful. In particular, they appreciate its ability to compel these countries to adopt stabilization and adjustment policies that they deem acceptable. They also support its role as the crisis manager in countries experiencing debt problems. In short, they value having an organization that can focus on the problematic areas of the global financial system, leaving them free to shape that system to suit their own needs.

The wealth and independence of the industrialized countries, particularly the United States, Japan, Germany, Great Britain and France, also ensures that they are the dominant force within the decision making structures of the IMF. Their dominance is significantly enhanced by two developments that have occurred in the IMF since its formation in 1944. First, the number of IMF Executive Directors has grown more slowly than the number of IMF member states. The original 39 member states were represented by a 12 member board of directors. Today the 184 members are represented by a board of 24 members. Originally, only the 5 biggest shareholders had their own executive directors and the remaining 34 member states were represented by the other 7 directors. This meant that each of these 7 directors represented on average slightly less than 5 states. Today, of the 24 member Board, in addition to the 5 executive directors representing the five largest shareholders another 3 directors represent single countries. Thus, today 16 directors represent the remaining 176 member states. This means that each of these directors represents on average slightly less than 11 states. In fact, some executive directors, for example the two directors representing sub-Saharan Africa represent considerably more than 11 states $^{27}$.

among industrialized countries and emerging markets with a view to promoting international financial stability.” The members of the G-20 are Argentina, Australia, Brazil, Canada, China, France, Germany, India, Indonesia, Italy, Japan, Korea, Mexico, Russia, Saudi Arabia, South Africa, Turkey, United Kingdom, and the United States. Id.

${ }^{27}$ See, IMF SURVEY, Special Supplement, September 2005 (for list of Executive Directors and their 
This change in the average size of the constituencies represented by the executive directors has an important impact on the power relations in the IMF's decision making process. It means that those states that have permanent representation on the Board have a distinct advantage in having their views heard in the Board. It is unlikely that a director who represents 10-11 states can advocate for the views of each of those states as effectively as a director who only represents one state. It is also unlikely that such a director can play the same active role in policy issues in the IMF as an executive director who represents only one state.

In this regard, it is important to note that each of the G-7 countries always has a national of their country on the Executive Board, despite the fact that only 5 of the 7 countries have appointed Executive Directors. In addition, the Eurozone member states hold 6-8 of the 24 seats on the Executive Board. Furthermore, in 5 out of 6 cases in which an Executive Director represents both developing and industrialized countries, the Executive Director is from an industrialized country, and the in the other 1, the Executive Director is usually from an OECD member state ${ }^{28}$. The result is that of the 24 directors, 11 are currently from OECD countries and 9 are from industrialized countries.

The numerical advantage of the industrialized countries' representation on the Executive Board is significant even though the Board tends to operate by consensus. The reason is that these countries, because of their permanent presence on the Board, are able to develop institutional memories and expertise in how to function in the IMF. This enhances their ability to negotiate effectively and to shape the issues and the decisions around which the consensus must form ${ }^{29}$.

constituencies); Ngaire Woods, "Governance in International Organizations: The Case for Reform in the Bretton Woods Institutions” in INTERNATIONAL FINANCIAL AND MONETARY IsSUES (UNDP, 1988);Rustomjee, Cyrus, IMPROVING SOUTHERN VOICE ON THE IMF BOARD: QUO VADIS SHAREHOLDERS? IN ACCOUNTABILITY OF THE INTERNATIONAL MONETARY FUND, at 23-25 (Cairn \& Wood, eds.) (Ashgate Publishing, 2005).

${ }^{28}$ See, IMF SURVEY, supra, note 27.

${ }^{29}$ See Ngaire Woods, Governance in International Organizations: The Case for Reform in the Bretton Woods Institutions, Woods, Globalization and International Institutions, in THE POLITICAL ECONOMY OF 
The result has been to enhance the G-7's control over the policy agenda in the IMF. However, because these countries are effectively independent of the IMF, they never have to live with the consequence of the policies that they make for the IMF's operations. This means that they can make policy that is only of limited interest to their own citizens but that is of immense interest to people in developing countries who have no ability to hold them accountable for their decisions or actions. This situation of decision makers having power with accountability to people who do not have to live with the consequences of their decisions but without accountability to those most affected by their decisions is a situation ripe with potential for abuse.

The second development relates to the composition of the voting rights of each member state. Each state's vote consists of 250 basic votes plus 1 vote for each SDR 100,000 it contributes to the IMF's general resources. The basic vote is intended to reflect the general principle of the sovereign equality of states. The remaining portion of the vote is intended to reflect the size of the country and its importance in the world economy. Since the establishment of the IMF in 1946, the number of total votes in the IMF has been increased due to the IMF membership growing from 39 in 1946 to 184 today and the need to expand the total resources of the IMF. However, there has been no change in the basic vote. The result is that today the basic votes form a significantly smaller portion of the total vote than was the case in 1946. In 1946 the basic votes accounted for $11.3 \%$ of the total vote. Today the basic vote accounts for only $2.1 \%$. This means that the portion of the IMF's voting system that offered the smaller and weaker states some counterweight to the dominance of the richest and biggest countries in the IMF has been reduced in importance ${ }^{30}$.

GLOBALIZATION, at 208-209. Carlo Cottarelli, Efficiency and Legitimacy: Trade-offs in IMF Governance, IMF Working Paper WP/05/107, 21-24 (2005) (discussing the overall scarcity of human resources at the IMF). Kahler, Miles, Internal Governance and IMF Performance 1-6 (prepared for Institute of International Economics' Conference on IMF Reform, 2005) available at http://irpshome.ucsd.edu/faculty/mkahler/ ; Rustomjee, supra note 27.

30 This information has been derived from IMF Annual Reports. Also see GOLD I, supra note 9, at 292294; Buira, Ariel, The Governance of the IMF in a Global Economy, in CHALLENGES TO THE WORLD BANK AND IMF 13, 14-15. Anthem Press, 2003; Carin, Barry and Angela Wood. ACCOUNTABILITY OF 


\section{B. Relations Between the IMF and Its Consumer Member States}

Since 1978 all the states which have utilized the financial services of the IMF are low or middle-income developing countries or the so-called transitional countries. For present purposes these consumer states can be divided into two groups. The first group consists of those countries that are classified as emerging markets and, under normal circumstances, have access to private financial markets. Many countries in this group need the IMF's support to satisfy private investors that they have adopted and are implementing good macroeconomic policies and that they are "suitable" for private investment. Thus even though this group of countries only needs IMF funding when they are unable to raise sufficient funds from private sources because of a debt or some other financial crisis, they are dependent on the IMF giving their economic policy performance a favorable review. This in turn is influenced by how they respond to the advice the IMF gives them in their annual consultations.

It is interesting to note that a number of these countries have recently pre-paid their obligations to the IMF so that they can try and escape from its oversight ${ }^{31}$. In addition, a number of the Asian countries have attempted to escape the constraints that the IMF may impose on them by building up sufficient reserves to withstand any future payments crisis that they may face ${ }^{32}$.

THE InTERnATIONAL MONETARY FUnD at 10-13. Ashgate Publishing, 2005; Rapkin, David P. and Jonathan R. Strand, Reforming the IMF's Weighted Voting System, 13-14 (Blackwell Publishing 2006); Truman, Edwin M., A Strategy for IMF Reform (Institute for International Economics, 2006).

${ }^{31}$ See, for example, IMF Press Release No. 05/19, Russian Federation Completes Early Repayment of Entire Outstanding Obligations to the IMF (Feb. 2, 2005); IMF Press Release No. 05/278, Argentina Announces Its Intention to Complete Early Repayment of Its Entire Outstanding Obligations to IMF (Dec. 15, 2005); IMF Press Release No. 05/275, Brazil Announces Intention to Complete Early Repayment of Entire Outstanding Obligations to IMF (Dec. 13, 2005); Chris Giles and Andrew Balls, Call for IMF Reform Draws Muted Echo, FinANCiAL TiMES, Feb. 24, 2006, at 3.

${ }^{32}$ For example, China's gross official reserves were projected at $\$ 829$ billion for 2005, India's reserves were projected at $\$ 139.5$ billion for 2005/2006, and Korea's reserves are projected by IMF staff to be at $\$ 3.9$ billion for 2005. See IMF Executive Board Article IV Consultation Reports for each country, available at http://www.imf.org. For an interesting discussion of the significance of the size of the reserves, see Lawrence H. Summers, Reflections on Global Account Imbalances and Emerging Market Reserve Accumulation, L.K.Jha Memorial Lecture, Reserve Bank of India, March 24, 2006, available at www.president.harvard.edu/speeches/2006/0324_rbi.html (showing that reserves of emerging market 
These efforts have been interpreted as a vote of no-confidence in the IMF and are posing an important financial challenge to the $\mathrm{IMF}^{33}$. Furthermore, to the extent that these countries succeed in their efforts to assert monetary independence, they will become a third group of member states that can relate to the IMF in ways that are more similar to those of an IMF supplier country than to those of consumer countries. To a significant extent, the current interest in governance reform at the IMF is attributable to the institution's and its more powerful member states' interest in keeping this emerging third group of countries engaged in the IMF.

The second group consists of those countries which because of their poverty or unstable political conditions are substantially dependent on official sources of funds. This group, in addition to needing the IMF's financial support, require its approval of their policies because their other official funders tend to rely on the IMF's advice in making their funding decisions.

While there are significant differences between the countries in the second group of IMF consumer states, they all share a common characteristic. Although the challenges that these countries face have a macroeconomic dimension, the primary cause of their social and economic, including macroeconomic, problems lies in the governance of their societies. In particular their problems are caused by weaknesses in their institutional arrangements and technical capacities which limit their ability to effectively make and implement policy. ${ }^{34}$ Although these structural issues are outside the scope of the IMF's specialized area of competence it has attempted to address them ${ }^{35}$. This means that increasingly, in both its policy advice and in the conditions that it attaches to its financing, the IMF is addressing issues like bankruptcy laws, legal and judicial reform, allocations of public budgets, privatization, environmental issues, social safety nets, and banking reform that are not monetary or macro-economic issues. The specificity and micro

Asian and oil exporting countries exceed short term debt due within one year by about $\$ 2$ trillion and growing each year by several hundred million dollars)

${ }_{33}$ Andrew Balls and Richard McGregor, G20 Calls for Reform of IMF and World Bank, FINANCIAL TIMES, Oct. 16, 2005.

${ }^{34}$ See, for example, The World Bank, Can Africa Claim the 21st Century? (2000); The World Bank, World Development Report: The State in a Changing World (1997).

${ }^{35}$ See Devesh Kapur, The IMF: A Cure or a Curse?, FOREIGN POL'y (June 1998) (hereinafter The IMF); Devesh Kapur and Richard Webb, Governance Related Conditionalities of the International Financial Institutions, G-24 Discussion Paper Series No.6 (2000); THE POLITICAL ECONOMY OF GLOBALIZATION. 
nature of these requirements highlight the evolution of the IMF from a monetary institution to a development financing organization.

The broadening range of issues addressed in its annual surveillance missions and in the conditions it attaches to its funding is changing the nature of the relationship between the IMF and these countries ${ }^{36}$. In the days of the par value system, the IMF limited its influence over national policy making by concentrating its advice and the conditions attached to its finance to discrete macroeconomic variables. This imposed a restraint on the IMF's involvement in domestic policy making because it left the member state’s government free to decide on the actual measures it would adopt to achieve these macroeconomic targets. The increased range of issues the IMF considers and the specificity with which it addresses these issues means that this restraint has now been removed. The result is that the IMF has become an active participant in the policy making process of this group of member states. In fact, because of its influence over their access to external financing, the IMF is often the decisive voice in this processes.

The combination of the IMF's gate keeping functions and its de facto role in national policy-making further tips the balance of bargaining power in favor of the IMF in both the annual consultations and in the negotiations with the consumer states over the policy conditions to be attached to IMF financing. Moreover, given the dominance of the G-7 and the other industrialized countries in the IMF, there is a significant risk (that has often in fact been realized $^{37}$ ) that these countries will use the IMF to impose their views of good political and economic policies on the developing countries. In fact, many people in developing countries already see the IMF more as a political organization that is biased in favor of the rich countries and their interests than as the technically specialized and politically neutral organization that it was intended to be.

\footnotetext{
${ }^{36} \mathrm{Id}$.

${ }^{37}$ See Kapur, The IMF, supra note 47, at 98 (quoting a supporter of the IMF in the U.S. Congress: the IMF "is in fact one of the best possible deals we could ever imagine: Its programs cost us nothing yet it provides enormous benefits for out economy and our foreign policy”); Paul Blustein, The Chastening: Inside the Crisis That Rocked The Global Financial System and Humbled the IMF (PublicAffairs, 2001) (exploring the Asian financial crisis of 1997 and the IMF's role in that crisis).
} 
This problem is exacerbated because the consumer countries are unable to effectively use the Board of Executive Directors or the Board of Governors to limit the staff and management's discretion in the IMF's operations. As we have seen above, the consumer states are imperfectly represented on the Board of Executive Directors. Furthermore, it is unrealistic to assume that the consumer states can hold the IMF accountable through their representative on the Board of Governors. There are two reasons for this. The first is that this is not the appropriate body in which to challenge individual operational management decisions. Second, it is not realistic to assume that a member state’s IMF Governor will be willing to raise specific operational issues during the infrequent meetings of the IMF Governors.

The IMF's expanded role in its developing country member states has also changed the range of actors with whom it must directly interact in these states. Prior to 1978, the IMF could reasonably limit its direct interactions to the Central Banks and the Ministries of Finance ${ }^{38}$. Today, however, the IMF's operations directly affect many, if not all, government ministries and the lives of all those people who will be governed by the policies that it helps make. This means that it is no longer feasible for the IMF to limit its interactions to the Central Bank or the Ministry of Finance. In fact, without directly interacting with a broader range of both governmental and non-governmental actors in the member states, the IMF is unlikely to obtain all the information it needs to play an effective policy making role. For example, it needs to consult with government ministries whose budgets and policies will be affected by the IMF's funding conditionalities. It also needs to consult with the legislators who must pass the laws that the IMF policies require. To be an effective and credible policy maker, the IMF also should hear the views of all those stakeholders who have the ability to influence the success or failure of those policy decisions and will be directly affected by them. To date, the IMF, utilizing informal procedures has consulted with some of these actors. However, it has not yet developed either formal procedures for ensuring that all relevant stakeholders are consulted or through which the government or citizens of these member countries can hold the IMF accountable for its actions in the policy making process.

\footnotetext{
${ }^{38}$ See IMF ARTICLES, supra note 7, at art. V, § 1.
} 
The IMF has recognized that its programs have become unduly intrusive. In 2002, it issued new guidelines on conditionality that are intended to make the conditions more focused on its core areas of competence and to reduce the number of conditions to those that are essential to the achievement of the program's objectives. These new guidelines, however are drafted in relatively non-specific terms and it is not clear how effective they will be in reducing the IMF's intrusion into its members domestic affairs, although they do appear to have resulted in some reduction in the average number of conditions attached to IMF financial programs. ${ }^{39}$

It is important to note, however, that a reduction in quantity of conditions does not necessarily translate into a reduction in intrusiveness, particularly given that the new guidelines allow the IMF to continue engaging in institutional and governance reform in the monetary and financial area. In addition, the previous IMF guidelines on conditionality also attempted to impose limits on the scope of conditionality but these were largely ignored in practice. ${ }^{40}$

\section{IMF Relations with the Citizens of its Member States}

The creators of the IMF, like the creators of most international organizations, believed that it was not necessary for the IMF to have any direct interaction with non-state actors. They assumed that it would be sufficient for the IMF to interact with its member states through their representatives on the Board of Governors and the Executive Board and, in its specific operations, through the Ministry of Finance and the Central Bank. The creators also assumed that

\footnotetext{
${ }^{39}$ See IMF, Guidelines on Conditionality (2002), available at http://www.imf.org/External/np/pdr/cond/2002/eng/guid/092302.pdf; Buira, Ariel, ed. Challenges to the World Bank and IMF: Developing Country Perspectives, pp. 55-90. Anthem Press, 2003; Eggers, Andrew et. al., Democratizing the IF in ACCOUnTABILITY OF THE INTERNATIONAL MONETARY Fund, at 40 (Barry Cairn \& Angela Wood, eds.) (Ashgate Publishing, 2005); Eldar, Ofer. "Reform of IMF Conditionality: A Proposal for Self-Imposed Conditionality.” 8 JOURNAL OF INT’L ECON. LAW 509 (2005).

${ }^{40}$ See Guidelines, IMF, Guidelines on Conditionality (2002), available at http://www.imf.org/External/np/pdr/cond/2002/eng/guid/092302.pdf; Buira, Ariel. An Analysis of IMF Conditionality, in Challenges TO THE WORLD BANK AND IMF: DEVELOPING COUNTRY PERSPECTIVES, at 67-69 (Anthem Press 2003). Eggers, Andrew et al. Democratizing the IMF, in ACCOUNTABILITY OF THE INTERNATIONAL MONETARY FUND, supra note 19 at 39-40
} 
this arrangement would provide sufficient accountability to all stakeholders because these representatives would be responsible to their governments, who in turn would be held accountable, through elections and administrative procedures, by their citizens.

These beliefs about the relationship of the IMF to non-state actors are no longer valid. Given, that the IMF now actively participates in the policy making processes of those member states that utilize its resources, it is no longer adequate for the IMF to limit its interactions to their Central Banks and Ministries of Finance. For the IMF to be an effective actor in the policy making process it must consult with both other governmental agencies and non-governmental actors. This means that the IMF is now interacting with non-state actors and the policies it is helping to make are directly affecting these non-state actors.

The basic principles of good governance which the IMF advocates so eloquently to the governments of its member states should guide its own conduct towards those directly affected by its policy-making activities ${ }^{41}$. After all, there is no obvious reason why the IMF, when it "descends" ${ }^{42}$ into the national policy-making process should be less accountable to those people directly affected by its decisions than other actors in this process. This means that the IMF needs to establish a formal and direct means through which those directly affected by its actions in the national policy making process can hold the IMF accountable. It is no longer sufficient for the IMF to assume that it can rely on indirect forms of accountability to these non-state actors.

To be sure there may be practical difficulties in designing an accountability mechanism

\footnotetext{
${ }^{41}$ For discussion of developments in and requirements for international organizational accountability, see Int'l Law Assoc. (ILA), Accountability of International Organisations- Berlin Conference Final Report (2004) (the author was a member of the ILA committee that drafted this report); Int'l Law Comm. (ILC), First Report on Responsibility of International Organizations, UN Doc. No. A/CN.4/532 (2003); ILC, Second Report on Responsibility of International Organizations, UN Doc. No. A/CN.4/541 (2004); ILC, Third Report on Responsibility of International Organizations, UN Doc. No. A/CN.4/553 (2005).

42 The analogy is to the law of sovereign immunity, according to which, a sovereign will loose its immunity to being sued when it "descends" into the market place and engages in activity that by its nature is commercial. See, for example, Alfred Dunhill v. Republic of Cuba, 45 U.S. 682, 96, S.Ct 1854 (1974) at 1862 (quoting Bank of the United States v. Planter's Bank of Georgia, 22 U.S. 904, (1824) . Also see Foreign Sovereign Immunities Act Foreign Sovereign Immunities Act, 28 U.S.C. §§1602-1611 (1976).
} 
that is both suitable for an international organization and respectful of the member state's sovereignty. However, these problems have been dealt by the multilateral development banks and there is no reason why they cannot be overcome by the $\mathrm{IMF}^{43}$.

There are other problems that arise because the IMF has no formal channels through which it can communicate with non-state actors in its member states. Under the current operating principles, the IMF, out of respect for the sovereignty of its member states, only communicates with non-state actors in a member state if it obtains the consent of the government, which can result in the IMF meeting with an inadequate range of non-state actors in its member states. Consequently, it is at high risk of making policy decisions for the country on the basis of insufficient information about the likely reception that the policies will receive and their chances of success. Furthermore, the failure to establish formal mechanisms through which it communicates with non-state actors and which are independent of the government has an adverse impact on the IMF's policies and its relations with the citizenry of these countries. They come to see the IMF as unapproachable and as an elitist, ideological institution that is uninterested in learning about the views of those who will be most affected by its policies. ${ }^{44}$

Another dimension to the IMF's relationship with non-state actors is the impact of its evolving operations on its relations with the citizens of its supplier states. Although these actors are not directly affected by the actions of the IMF, many of them see themselves as being indirectly affected by the IMF's operations. They argue that it is their taxes that support the IMF and that, currently, these taxes are being spent to support policies and operating principles that they oppose. Consequently, these citizens have begun demanding changes in the operations of

\footnotetext{
${ }^{43}$ The World Bank has established the Inspection Panel partly for this purpose. See generally Daniel D. Bradlow, International Organizations and Private Complaints: The Case of the World Bank Inspection Panel, 34 VA. J. INT'L L. 553 (1994); IBRAHIM F. I. SHIHATA, THE WORLD BANK INSPECTION PANEL: IN PRACTICE (2nd ed., 2000); Daniel D. Bradlow, Private Complainants and International Organizations: A Comparative Study of the Independent Inspection Mechanisms in International Financial Institutions, 36 GEO. J. INT’L L. 403, 411-420 (2005).

${ }^{44}$ The IMF has made some efforts to address this problem. In October 2003 it issued guidelines for IMF staff on interacting with civil society organizations. See IMF, Guide for IMF Staff Relations with Civil Society Organizations, October 10, 2003, available at http://www.imf.org/external/np/cso/eng/2003/101003.htm.
} 
the IMF. The NGOs that represent them have used their access to their own governments and to the media in the industrial world to raise these concerns. These NGOs have had some success in influencing the IMF. Ironically, the influence of these NGOs in the IMF is derived in part from the disproportionate influence and power of the industrialized countries in the IMF.

\section{The IMF's Relations with Other International Organizations}

The original conception of the creators of the United Nations system was that each specialized agency, of which the IMF is one, would exercise its authority within the limited scope of its specialization and that the U.N. Economic and Social Council would be the forum in which their activities would be coordinated ${ }^{45}$. Each specialized agency, in part to facilitate this coordination, entered into a relationship agreement with the United Nations. This relationship agreement was ostensibly based on the fact that the specialized agency was subordinate to the United Nations. The relationship agreement between the IMF and the $\mathrm{UN}^{46}$ however amounts to a declaration of independence. While it acknowledges that the IMF is a specialized agency of the UN, it relieves the IMF of any significant responsibilities to the UN and denies the UN any meaningful role in the affairs of the IMF.

The effective independence of the IMF from the UN has become a problem as the scope of the IMF's operations has expanded beyond its original monetary function. Now that the IMF is involved in such issues as law reform, poverty alleviation, labor issues, social welfare, budgetary allocations for health and education, environment, and trade liberalization, its operations are encroaching into the jurisdiction of other specialized international organizations like the World Bank, the ILO, WHO, UNICEF, UNEP and the WTO.

\footnotetext{
45 See UN CHARTER, art. 61-72 (establishing EcoSoc and setting out its purposes and functions).

${ }^{46}$ See Agreement between the United Nations and the International Monetary Fund, entered into force 15 November 1947, 109 U.N.T.S. 340.
} 


\section{E. Three Legal Issues}

The three legal issues are uniformity, the treatment of political considerations by the IMF and the legal nature of the standby arrangement. It is important to note that each of these issues arises from the way in which the IMF has interpreted its mandate and are not explicit requirements of the Articles of Agreements. They are each discussed below.

As was explained above, the IMF, in implementing its mandate, developed the principle of uniformity. This principle results in the IMF granting all states equal access to its financing and other services without drawing any distinctions between its member states based on their wealth, size, level of development, or importance in the international monetary system. It has had the effect of protecting the richest countries from having to grant special treatment to developing countries in the use of the IMF's general resources. It has also offered developing countries some protection against being discriminated against by the richer member states ${ }^{47}$.

The Articles of Agreement also require the IMF, when conducting its annual consultations with its member states and when designing the conditions it attaches to its funding, to pay due regard to social and political conditions in the country. ${ }^{48}$ The IMF has historically interpreted this requirement as prohibiting it from being influenced by political (that is noneconomic) considerations in its dealings with its member states. ${ }^{49}$

These two interpretations of its legal mandate pose a number of problems for the IMF. First, the principle of uniformity made sense when the IMF functioned purely as a monetary institution and all its member states, in fact, were utilizing its services. However, it does not

\footnotetext{
${ }^{47}$ A good example of how the uniformity principle worked in favor of developing countries is the original decision to allocate SDRs among all member states according to their quotas rather than to limit it to the richest countries. See Gold I, supra note 10, at 469-470; Mohammed, Aziz Ali, Who Pays for the IMF? in CHALlENGES TO THE WORLD BANK AND IMF 37 (Ariel Buira, ed.) (Anthem Press, 2003); Ferguson, Tyrone, The SDR and Related Questions: The Origins of the Quest for Participation in Decision Making in The Third World and Decision Making in the International Monetary Fund: The Quest for Full and Effective Participation 119-147 (Pinter Publishers 1988).

${ }^{48}$ See IMF ARTICLES, supra note 6, at art. IV, § 3.

${ }^{49}$ See Gold. See also IMF ARTICLES, supra note 6, at art. XII, § 4(c).
} 
make sense when its services are only being utilized by its developing country member states. For example, uniformity precludes the IMF from creating mechanisms that protected the poorest and weakest states from the undue exercise of power by the richest and most powerful states in the decision-making bodies of the IMF. Another example of the problems that uniformity creates is the Poverty Reduction and Growth Facility (PRGF). When the IMF decided that it needed to create a special facility exclusively for the poorest of its member states, it could not do so with its general resources but had to create a special fund for this purpose. Since this requires specific contributions from member states, the PRGF has inevitably become politicized. Both examples serve to demonstrate that the performance of the IMF could be improved if it could distinguish between different categories of member states both in regard to its services and resources and in its governance arrangements.

Similarly, the IMF's interpretation of the requirement that it pay due regard to social and political conditions in its member countries made sense when the IMF's operations were limited to monetary issues. However, it is neither prudent nor principled for an organization that attaches conditions to its funding that relate to governance, corruption, budgetary allocations and privatization to pretend that it does not consider political and social factors in its operations. The only function that the current interpretation serves is to obscure what political considerations the IMF does view as relevant to its operations, what principles it applies in making its decisions, and what process it follows in reaching them. The lack of clarity on this issue also leaves undefined the outer limits of the IMF's specialized economic mandate ${ }^{50}$. This results in IMF decisions appearing arbitrary or influenced by the interests of its richer and more powerful member states, thereby undermining confidence in the fairness and objectivity of the IMF.

A third legal problem for the IMF arises from the IMF's characterization of the legal nature of the standby arrangement through which it provides much of its financing to its member states. The standard documentation used in these transactions are a letter of intent, usually written by the government of the member state to the IMF, and the decision of the IMF's Executive Board. For many years the IMF has argued that this arrangement is sui generis and is

\footnotetext{
${ }^{50}$ See Bradlow, supra note 8, at 66-70.
} 
not a legal contract ${ }^{51}$. Until a few years, the IMF relied, in part, on this characterization to avoid publicizing the member state's Letter of Intent ${ }^{52}$. It also justifies this characterization by arguing that it protects a member state that does not meet the performance criteria or other requirements of its standby arrangement from incurring any legal liability.

The IMF's formalistic interpretation of the nature of this transaction had a certain utilitarian value when the IMF functioned as the manager of the par value system, and the conditions attached to the financing included a change in the par value of a currency. It is not, however, clear that the same considerations apply to its current development functions. In fact, the IMF seems to have recognized as much. In recent years, as part of its efforts to promote transparency, it has encouraged its member states to publish its Letter of Intent. ${ }^{53}$ Nevertheless, the IMF has not changed its view of the legal nature of the standby arrangement. This is problematic for two reasons. First, if the stand by arrangements, like World Bank contracts, were classified as international agreements they would be registered with the United Nations and would become public documents ${ }^{54}$. Consequently, the IMF could require, rather than encourage, member states to publish these letters of intent. This would more effectively advance the IMF's goal of promoting transparency than the current arrangements.

Second, as IMF transactions become more complex and the IMF increases the number of conditions it attaches to its standby arrangements there is a greater need for these agreements to be subjected to predictable principles of interpretation. The reason is that, when dealing with conditionalities like benchmarks or those related to governance, for example, it is possible for disagreements to arise about what constitutes sufficient compliance with the terms of the standby to justify disbursing the next tranche of the funds. If these transactions were viewed as international agreements, they would be subject to predictable public international law rules for

\footnotetext{
${ }^{51}$ See GOLD I, supra note 10, at 52, 464-66.

${ }^{52}$ See id.

${ }^{53}$ For the text of IMF agreements, see http://www.imf.org. See also IMF, The Fund's Transparency Policy (Statement by Horst Kohler) (2002); IMF, Public Information Notice No. 02111 (2002); IMF, ANNUAL REPORT, Chapters 7-8 (April 2005) (providing details on the IMF's attempts at increased transparency for the benefit of stakeholders and other nonofficial groups).

${ }^{54}$ See U.N. CHARTER art. 102 (1945).
} 
interpreting international agreements ${ }^{55}$. Under the current IMF treatment of standby

arrangements there are no obviously applicable rules of interpretation. In addition, if they were seen as international agreements, the standby arrangements would include dispute settlement clauses that would establish clear procedures for resolving disputes between the IMF and the member state over the interpretation and implementation of the standby arrangement ${ }^{56}$.

\section{Problems Created by the Five Distortions}

The five distortions discussed above are creating a number of problems for the IMF. The most significant of these are discussed below.

\section{A. The Disconnect Between Power and Responsibility ${ }^{57}$}

As was discussed above, the industrialized countries, particularly the G-7, have accumulated great power in the IMF even though they are not interested in the services of the IMF for themselves. This enables them to make policy for the IMF without having to live with the consequences of the IMF's policies and actions. Consequently, most of their own constituents have little interest in the IMF or its policies and limited incentive to support their government's financial contributions to the IMF. The governments of these countries, therefore, are free to develop their policies for the IMF without paying appropriate attention to the concerns of the developing countries or to the situations in which these policies must be implemented. In addition, this situation amplifies the voices of those Northern NGOs who have an interest in the

\footnotetext{
${ }^{55}$ These rules would include the Vienna Convention on the Law of Treaties (U.N. Doc. A/CONF. 39/27, May 23, 1969) and the Vienna Convention on the Law of Treaties Between States and International Organizations or Between International Organizations (U.N. Doc. A/CONF. 129-15) (this treaty has not yet entered into force). Also See Gold I, supra note 10, at 446-447.

${ }_{56}$ One Model that the IMF could follow in drafting dispute settlement provisions is the arbitration clause contained in the general conditions incorporated in all IBRD loan agreements and all IDA credits. See IBRD, General Conditions for Loans, July 1, 2005, Article VIII, available at http://siteresources.worldbank.org/INTTOPGENCON/Resources/IBRD_GC_05.pdf; IDA, General Conditions for Credits and Grants, July 1, 2005, Article VII, available at http://siteresources.worldbank.org/INTTOPGENCON/Resources/IDA_GC_05.pdf

${ }^{57}$ See generally ILA, supra note 52, at Part 1, § 1.
} 
IMF and other international development issues. While many of these NGOs have utilized this situation to achieve a great deal of good, the reality is that they, like their governments, can influence the policy of the IMF without having to live with the consequences of their proposals.

One result of this situation is that proposals that impose substantial burdens on already overloaded developing country governments or that make unrealistic assumptions about the access of these countries to private financing are able to receive serious consideration ${ }^{58}$.

\section{B. The IMF Management and Staff's Lack of Accountability ${ }^{59}$}

As was discussed above, the IMF’s existing channels of accountability are insufficient. The problems in the existing channels of accountability have three important operational implications for the IMF. The first is that the IMF staff and management are effectively operating without any accountability. However, if the IMF staff are making policy in the member states, there is no obvious reason why they should be less accountable to those affected by the policies than the other participants in the policy-making process. In fact, it undermines the IMF staff and management's credibility when they advocate accountability as an aspect of good governance in its member states but do not apply the principle to themselves.

The second is that the IMF does not provide much guidance to the staff on how they should perform their responsibilities when they act in this policy-making capacity. For example, it does not give them formal guidance on such issues as what obligations they owe to those affected by the policies, what factors they should consider in making decisions in this process, and to whom they owe their primary responsibility. The lack of such guidance makes it possible for each staff member or mission team to exercise great discretion in its operations. It also makes it hard to hold the staff accountable. In this regard it is important to note that, unlike the World Bank, the IMF does not have a publicly available operational manual that contains the

\footnotetext{
${ }^{58}$ See, for example, Omnibus Consolidated and Emergency Supplemental Appropriations Act, Pub. Law No. 105-277 (1998); Meltzer Commission, Report of the International Financial Institution Advisory Commission (2000).

${ }^{59}$ See generally ILA, supra note 52, at Part 1 , § 1.
} 
operational policies and procedures that its staff should follow in the conduct of their duties ${ }^{60}$.

Third, the IMF is performing its policy-making functions without establishing any formal mechanisms through which those non-state actors most affected by its actions can communicate directly with the IMF. In fact, the IMF is not unaware of this problem and it often engages in informal communications with these affected parties ${ }^{61}$. However, this means that the IMF, in consultation with the government of the member state, is choosing with which non state actors it communicates and is setting the terms for this communication. A more formal procedure for communication with these non-state actors -- such as an explicit requirement that all IMF missions hold a public hearing in the country they are visiting or an explicitly recognized right to make written submissions -- would ensure that many more interested non-state actors have a meaningful opportunity to communicate with the IMF. The IMF's failure to establish such procedures contradicts the principles of participation and the need for transparent governance procedures that it advocates to its member states. It also suggests that the IMF is often making policy without having access to all the relevant information.

\section{The IMF and Other International Organizations}

The expansion of the IMF's scope of operations has resulted in the IMF encroaching into the areas of responsibility of other specialized agencies. While in some cases the IMF may attempt to have communications with these organizations, there is no formal agreement designed to ensure regular communications at the staff level. The only international organizations with which the IMF appears to have formal arrangements are the World Bank ${ }^{62}$ and the World Trade Organization. The result of this situation is that the IMF is making policies and taking action in

\footnotetext{
60 Daniel D. Bradlow, supra note 54.

${ }^{61}$ See for example, EvAlUATION OF SURVEILlANCE, supra note 4; External Evaluation of ESAF, supra note 4.

${ }^{62}$ For a history of this relationship, see Jacques Polak, The World Bank and the IMF: A Changing Relationship, in THE WORLD BANK: ITS FIRST HALF CENTURY II 473 (1997). For recent developments in it see, IMF Press Release No. 06/65, IMF Managing Director Rodrigo de Rato and World Bank President Paul Wolfowitz Initiate Deeper Measures to Review and Enhance IMF-World Bank Cooperation (March 29, 2006).
} 
these new areas without necessarily having the technical expertise to do so and without adequate consultation with the appropriate specialized agency ${ }^{63}$. It may hire consultants to work on these issues, but it does not have the in-house expertise to fully evaluate the work of the consultants. This situation will continue until the IMF either hires people with the necessary technical skills or establishes some sort of cooperative arrangement with the relevant specialized agencies. This creates a significant risk that the IMF will have inadequate policies in these areas or that it will assign a lower priority to these issues than may be appropriate in particular situations.

The UN specialized agencies’ implicit acquiescence in the IMF usurping parts of their responsibilities also has adverse consequences for the functioning of the UN system as a whole. It is resulting in a concentration of power in organizations like the IMF and the World Bank to the detriment of the other specialized agencies. This exacerbates the IMF's tendency to maintain that it has the "correct" answer for the major development challenges that its member states face. The inability of other specialized agencies to effectively challenge the IMF's position increases the risk of the IMF giving wrong policy advice. Furthermore, the developing countries, because the IMF has the money, have no real choice but to follow the advice of the IMF.

\section{Interpretation of Articles of Agreement}

The IMF has not fully recognized that the expanding scope of its activities is calling into question its interpretation of its own Articles of Agreement. In particular, it raises questions about the limits on its permissible scope of activities and about the IMF's claim to be a "nonpolitical” body. The IMF has failed to define the limits of its mandate or to stipulate a principled basis on which it determines what issues it is willing to address and which issues are outside its mandate because of their inherently political or non-economic nature. This failure subjects the IMF to the charge that it is acting in an arbitrary and capricious fashion in interpreting its articles.

${ }^{63}$ See generally Daniel D. Bradlow \& Claudio Grossman, Limited Mandates and Intertwined Problems: A New Challenge for the World Bank and the IMF, 17 HuM. RTS. Q. 411 (1995). 
$\underline{\text { V. A Proposed Solution to the Problems Caused By the Five Distortions }}{ }^{64}$

The solution proposed in this section is based on three assumptions:

1. Good governance of the international financial and economic system requires an organization like the IMF;

2. Given the current global context it is not politically possible to create a new “ideal” IMF and that therefore we need to focus on reforming the current IMF. Thus, the comprehensive reform program proposed in this section of the paper is designed to create the best IMF possible in the current global context and its likely evolution over the next few years. This means an IMF that:

i) has a limited but realistic mandate;

ii) makes a positive and coherent contribution to global economic governance; and

iii) that wins the confidence and support of all its member states.

3. The IMF, like all international organizations, should conform to the principles of good administrative governance that are applicable to all national and international public institutions. These principles are ${ }^{65}$ :

a. transparency, which means that there should be reasonable access to information for all interested parties and that all stakeholders should be able to see and understand the decision-making process in the institution,

b. predictability, which means that the decisions and actions taken by the institution should be based on understandable principles and processes that are applied in a consistent manner,

c. participation, which means that all interested stakeholders should be able to have some input into the decision making process of the institution,

\footnotetext{
${ }^{64}$ For an interesting overview of reform initiatives in the IMF, see Angela Wood, Structural Adjustment for the IMF (2001), at www.brettonwoodsproject.org. See also generally Carin, Barry and Angela Wood, ACCOUNTABILITY OF THE INTERNATIONAL MONETARY Fund (Ashgate Publishing, 2005); Truman, Edwin M., A STRATEGY FOR IMF REFORM (Institute for International Economics, 2006).

${ }^{65}$ Benedict Kingsbury et. al., The Emergence of Global Administrative Law, LAW \& CONTEMP. PROBS., Summer-Autumn 2005, at 37.
} 
d. reasoned decision-making, which means that the institution should provide a rationale for its decisions, and

e. accountability, which means that those affected by the decisions and actions of the institution, its staff, and management should be able to hold these actors responsible for their decisions and actions.

Given the complexity of the nature of the relations between international organizations and their member states, it is likely that carrying out all the proposed reforms will be a long term project. However, it is possible to divide this reform program into short-, medium- and long-term components. The distinction between these categories is based on who must act to implement the reform proposal. Thus, short-term items are those which only require action by the IMF staff and Executive Board acting on their own authority. Medium term items are those that are more politically difficult and will require the participation of the Governors of the IMF. The third category includes those items that will require an amendment to the Articles of Agreement or at least will require the agreement of each of the member states, including the agreement of their legislatures. It should be noted that the IMF has begun to implement at least some aspects of the proposed reform agenda.

\section{A. Short-Term Reform Agenda: Those Actions That the Managing Director and Board of Directors Acting on Their Own Authority Can Take}

These actions can be divided into the following 6 categories:

\section{1) Actions to Make the IMF More Responsive to Its Developing Country Member States:}

a) Allow the member state's governor to the IMF or his/her representative to participate in any discussion in the Executive Board on the member state. This would include discussions about the staff report following the annual IMF surveillance mission to the country and about any 
proposed IMF program and financing for the country ${ }^{66}$. This reform is roughly analogous to the situation in the United Nations Security Council ${ }^{67}$. In this case, states who are not members of the Council but have a direct interest in the matter being considered by the Council can ask for permission to address the Council and participate in the Security Council discussions but not its vote. For many countries the issues being discussed about the country in the IMF Executive Board can be as momentous as those that can arise in the U.N. Security Council. It should be noted that currently it can happen that a representative of a member state attends Executive Board meetings on that country. However, the proposal is to formalize this process so that it is included in the Board's bylaws and/or operating procedures. Such an action will have two beneficial effects. First, it will encourage member states to engage more actively in Board discussions on the country. Second, it will enhance the channels of communications between the IMF and its consumer member states, particularly those that do not have direct representation on its Board.

b) Give more resources to the Executive Directors representing IMF consumer countries so that they can more effectively represent their constituents ${ }^{68}$. This includes both more staff and more financial resources.

c) Establish formal procedures for how the IMF will consult with non-state actors during its Article IV consultations with its member countries and when developing a program for any member state that wishes to use its financing facilities. This procedure should create a meaningful opportunity for non-state actors to submit information and express their views to the IMF.

d) Establish a formal mechanism through which non-state actors as well as civil servants who feel that they cannot safely or freely participate in any meetings that the IMF might hold with non-state actors can communicate with the IMF. This mechanism should enable such actors to make written submissions to the IMF. It would also provide a mechanism for communication with non-state actors in those states in which the government will not allow

\footnotetext{
${ }^{66}$ See Jose De Gregorio et al., An Independent and Accountable IMF: Geneva Reports on the World Economy (1999).

${ }^{67}$ See, eg., Frederic L. Kirgis, Jr., International Organizations in Their Legal Setting (2nd ed. 1993).

${ }^{68}$ The IMF has begun to provide some more resources to the African Executive Directors. See Buira, Ariel, The Governance of the IMF in a Global Economy, supra note 78, at 24-26.
} 
the IMF to meet with non-state actors.

e) Establish an IMF-NGO Liaison Committee in which a group of NGO representatives, elected on a regional basis, can meet on a regular basis with senior IMF staff to discuss issues of concern to NGOs and other non-state actors around the world ${ }^{69}$.

f) The IMF should formalize its participation in the World Bank-Parliamentary Network or create its own network. ${ }^{70}$

g) Increase the number of staff, particularly senior staff hired from consumer states.

\section{2) Actions to Make the IMF More Transparent}

a) The IMF should adopt a policy of publicly releasing drafts of all official reports and policies, redacted to remove all market sensitive information, and submitting them to public comment before the final reports or policies are adopted. The IMF has improved its information disclosure policy but it usually only releases final reports and policies ${ }^{71}$.

b) The IMF should adopt a policy of releasing the transcripts of its Board Meetings in a timely manner. ${ }^{72}$

c) The process for selecting the Managing Director and senior IMF staff should be opened to citizens of all member states and there should be a selection process, including interviews, that is understandable to the public. ${ }^{73}$

d) The IMF needs to develop and make publicly available a manual of all its operating policies

${ }^{69}$ The World Bank has had such a committee for a number of years. See World Bank and Civil Society, available at http://www.worldbank.org/civilsociety.

${ }^{70}$ See IMF, Report of the Working Group of IMF Executive Directors on Enhancing Communication with National Legislators (Jan. 15, 2004), available at http://www.imf.org/external/np/ed/2004/ecnl/index.htm.

${ }^{71}$ For the IMF information disclosure policy, see http://www.imf.org. The IMF set an important precedent for releasing drafts of policies and procedures when it published its draft decision on establishing an independent evaluation office before the decision was taken by the Board to do so. Ultimately, the Board decided to establish such an office and did so in 2002. See http://www.imf.org/external/np/ieo. Another important precedent was the IMF's use of notice and comment period following the announcement of the new conditionality guidelines. Bradlow, supra note 54 .

${ }^{72}$ See, for example, "A Guide to Meetings of the Board of Governors of the Federal Reserve System, available at http://www.federalreserve.gov/boarddocs/meetins/sunshine.htm ;

${ }^{73}$ SUCH A SELECTION PROCESS WAS USED IN FINDING THE NEW DIRECTOR OF UNDP. SEE 
and procedures. ${ }^{74}$ This publication would be analogous to the World Bank's operating manual ${ }^{75}$. While such a manual may not have been necessary when the IMF was operating under the par value system, the increased complexity of its operations makes such a manual a requirement. This publication would detail the responsibilities of the IMF staff and the procedures that they should follow in each situation. The publication of this information would enable those people affected by the IMF's actions to understand how IMF policy is made and whether the IMF has acted in conformity with its own rules and procedures in all cases.

\section{3) Actions to Make the IMF More Accountable:}

a) The IMF Managing Director and the Deputy Managing Directors should be subject to a process of periodic evaluation during their term of office. In this regard, it would be useful for the IMF to consider adopting the example of the New Zealand government, which negotiates a contract with the Governor of its Reserve Bank that establishes performance standards against which the Governor's performance can be evaluated. ${ }^{76}$

b) The publication of a manual of all the IMF's operating policies and procedures would enable those people affected by the IMF's actions to determine whether the IMF staff and management have acted in conformity with the IMF's operating rules and procedures in all cases and to hold them accountable for non-conforming actions.

c) Establish an ombudsman at the IMF who has the power to receive and investigate complaints from any person, organization, or state, that feels that the IMF has not been acting in conformity with its mandate. This official should have the power to publish an annual report that discusses the investigations he/she has conducted and to make recommendations to the Board of Directors on how to improve the functioning of the $\mathrm{IMF}^{77}$.

d) An independent review panel should evaluate the policies of the IMF to assess their impacts

\footnotetext{
${ }^{74}$ Bradlow, supra note 54.

${ }^{75}$ See, http://www.worldbank.org.

${ }^{76}$ See Reserve Bank of New Zealand, Policy Targets Agreement 2002 (agreement between the Minister of Finance and the Governor of the Reserve Bank of New Zealand), http://www.rbnz.govt.nz/monpol/pta/.

${ }^{77}$ See, Bradlow, supra note 54.
} 
on poverty and the environment. This panel should also be charged with making recommendations on how the IMF, acting consistently with its mandate (see below) could improve its policies so that their potential to have a positive effect on poverty and the environment is maximized. The IMF Evaluation Office may be the appropriate office to perform this role ${ }^{78}$.

\section{4) Actions to Better Coordinate the IMF's Activities with Other International Organizations}

a) Establish an independent expert panel to review the IMF's relations with other international organizations and to make recommendations on how the IMF, acting in conformity with its specialized mandate can most effectively coordinate its activities with these organizations. The IMF is beginning this process by reviewing its relationship with the World Bank ${ }^{79}$. However, it also needs to undertake similar reviews of its relations with the G-20, Financial Stability Forum, and other inter-governmental and international organizations, particularly the other specialized UN agencies.

The commission reviewing the relationship between the World Bank and the IMF should consider such options as merging the two institutions and revising the division of labor between them. For example, one option that it should consider is defining their responsibilities not according to function but according to the level of wealth of the country and the type of financing sources on which it relies. For example, the IMF would deal only with the problems of emerging markets that have access to private markets. The World Bank would have deal exclusively with countries that are dependent on official sources of funds. The issues of primary concern to industrialized countries would be addressed in other fora. The IMF and World Bank would only participate in these fora to the extent necessary to

\footnotetext{
${ }^{78}$ See InTERNATIONAL MONETARy FUnD, Making the IMF's Independent Evaluation Office Operational (Aug. 2000), at http://www.imf.org/external/np/eval/evo/2000/Eng/evo.htm.

${ }^{79}$ See IMF, IMF Managing Director Rodrigo de Rato and World Bank President Paul Wolfowitz Initiate Deeper Measures to Review and Enhance IMF-World Bank Cooperation, Press release March 29, 2006, http://www.imf.org/external/np/sec/pr/2006/pr0665.htm.
} 
understand how the issues being discussed would affect their areas of responsibility ${ }^{80}$

\section{5) Actions to Better Match IMF Skills to the Tasks it Performs:}

a) Change the skill mix in the IMF to make it more suitable to the functions the IMF defines as within its mandate. This will mean hiring more people with diverse social science expertise. This action will be less necessary if the IMF has better coordinated relations with other international organizations.

\section{6) Legal Actions:}

a) The Board of Directors, after a notice and comment period, should issue a decision defining the scope of the IMF's specialized mandate ${ }^{81}$. This decision, which would be part of the operational manual referred to above and would also help define the meaning of the restrictions on the IMF taking political considerations into account in its operations ${ }^{82}$. It would also help distinguish the IMF from other international organizations. The resulting clarity about the IMF's mission will enhance both the transparency and accountability of the IMF.

b) The Board of Directors should abandon the principle of uniformity and should explicitly categorize countries according to their wealth and level of economic development.

c) The IMF needs to clarify the legal nature of the standby arrangements.

\footnotetext{
${ }^{80}$ For a discussion of the problems with the IMF being involved in poverty alleviation and PRGF, see Stiglitz, supra note 4; Eldar, supra note 19, at 515-16, 515 n. 31.

${ }^{81}$ It is not unprecedented for the IMF to use a notice and comment period before finalizing its operational policies. This was done in the case of the 2002 Guidelines on Conditionality. See Bradlow, supra note 62; infra note 85.

${ }^{82}$ See IMF ARTICLES, supra note 6 , at art. IV, $\S 3$.
} 


\section{1) Actions to Make the IMF More Responsive to its Developing Country Member States:}

a) Begin the process of restructuring the Board so that it includes more developing country representatives. The steps that should be taken in the short term are:

i. all Board constituencies that include both consumer and supplier countries should commit to only choosing representatives from consumer countries as its Executive Directors; and

ii. the member states of the Euro-zone should publicly state their intention to consolidate their representation on the IMF's Board of Directors over time. ${ }^{83}$

b) Make some adjustments in the votes of those member states whose quotas result in them being underrepresented in the deliberations of the IMF. This means there should be both an increase in the votes allocated to those member states whose quotas are not an accurate reflection. It should be noted that this is similar to the Managing Director's current proposal to increase quotas. However, it is unlikely that a change in quotas alone will lead to any significant changes in the operations of or decision making in the $\mathrm{IMF}^{84}$.

c) Change the formula for calculating quotas so that it is based on purchasing power parity exchange rates rather than the current basis. This will have the effect of increasing the voting power of some of the emerging market countries, particularly in Asia. ${ }^{85}$

\footnotetext{
${ }^{83}$ Edwin M. Truman, Rearranging IMF Chairs and Shares: The Sine Qua Non of IMF Reform, IIE Conference on IMF Reform (Sept. 23, 2005); Truman, Edwin M., A STRATEGY FOR IMF REFORM (Institute for International Economics, 2006).

${ }^{84}$ The IMF Managing Director acknowledged this in response to a question. See, Rodrigo de Rato, "Transcript of an Address to the Foreign Correspondent's Club of Japan”, Tokyo, August 3, 2006 available at http://www.imf.org/extermal/np/tr/2006/tr06083.htm (in response to a question on the likely impact of the change in quotas and votes on IMF policy, he said “...I do not think that the institution will change its views”) Also see, IMF, The Managing Director's Report on the Funds Medium-Term Strategy (September 15, 2006), at http://www.imf.org/external/np/omd/2005/eng/091505.pdf; IMF, ${ }^{85}$ Buira, Ariel, The Governance of the IMF in a Global Economy, in Challenges to the IMF and World Bank: Developing Country Perspectives 13, 19-21 (Anthem Press, 2003); Rustomjee, supra note 40. It is
} 
d) The IMF should increase the number of alternate directors that can assist each director in more effectively representing the members of his/her constituency. ${ }^{86}$ In this regard, it should be noted that Trevor Manuel, the South African Minister of Finance, has proposed that there should be one Alternate Executive Director for each 8 countries in a constituency ${ }^{87}$. Since this will lead to a more unwieldy board, the IMF may need to give thought to delegating more responsibility to Board committees.

e) The Board of Governors can approve the restructuring of Board constituencies so that the Eurozone countries are granted one seat on the Board with the combined voting power of all the Eurozone countries. This will have the effect of freeing up at least 2 seats on the Board which can then be allocate to new constituencies that are constructed to enhance developing country representation at the Board level, for example by reducing the size of the African constituencies. ${ }^{88}$ While reviewing the composition of Board constituencies, it should reevaulate, within the constraints of its Articles, the desirability of having 3 single country constituency seats on the Board ${ }^{89}$.

f) The IMF should consider moving from its current practice of making decisions on the basis of consensus to making decisions on a basis that better reveals the preferences of those who will be most affected by the decisions. ${ }^{90}$ One possibility would be for the IMF to require separate votes by those Executive Directors who represent developing countries and those who represent industrialized countries. Any decision would only be adopted if it commanded a majority of both groups. ${ }^{91}$ This would improve the responsiveness of the IMF to the

interesting to note that recently there have been suggestions that the US has been calling for the use of purchasing power parity in calculating UN contributions. See also Mark Turner, China and Russia Bridle at Paying UN More, FINANCIAL TIMES (LONDON), March 25, 2006.

${ }^{86}$ See IMF, By-Laws, Rules, and Regulations, § 14 (d). See art. XII. § 3.

${ }^{87}$ Wray, Quentin, IMF revolution still a long way off, says Manuel, BUSINESS REPORT, August 4, 2006 at 1.

${ }^{88}$ See Truman, supra note 78; Rustomjee, supra note 40.

${ }^{89}$ Article XII Section 3(c), for example, imposes some limits on the ability of the IMF to eliminate these seats on the Board.

${ }^{90}$ The IMF Articles of Agreement appear to offer some flexibility in voting because they only stipulate that decisions must be made "by a majority of the votes case" without defining how this "majority" is defined. See Articles XII Section 5(c).

${ }^{91}$ Other organizations have also adopted this strategy. For example, Global Environmental Facility (GEF), Rules of Procedure for the GEF Council, § 12, available at http://www.gefweb.org/participants/Council/Council_Rules/English_Council_Rules.pdf. 
interests of both its supplier and consumer member states.

\section{2) Actions to Improve the IMF's Relations with other International Organizations:}

a) Establish formal and more extensive links between the IMF and other relevant international organizations (eg. United Nations, WTO, World Bank, UNICEF, WHO, ILO, etc.) at both the senior management and staff levels. These links should include regular meetings, staff exchanges, regular exchanges of information and reports and other publications, participation in joint missions to countries and formal agreements on the division of labor and responsibility between these organizations. It should also include a means for resolving any disputes that may arise between the parties.

b) The IMF should renegotiate its Relationship Agreement with the UN. The objective of this exercise would be to clarify the IMF's responsibilities to the UN and to enhance the ability of the UN to ensure the IMF fully respects the jurisdiction of other specialized agencies.

\section{Long Term Actions: Those Actions That Require Ratification By the Member States}

\section{1) Actions to Make the IMF More Responsive to Its Developing Country Member States:}

a) The IMF should amend the Articles of Agreement to increase the basic votes to at least its original proportion in the total votes at the IMF and to facilitate future increases in both basic votes and in the quota formula. ${ }^{92}$ It should be noted that the MD has proposed an increase in the basic votes as part of his governance reform proposals.

b) Amend the Articles of Agreement to introduce a qualified voting procedure that requires that any decision can only be adopted if it is supported by both a majority of the votes cast and a majority of the member states. ${ }^{93}$

c) Amend Article V Section 1 to require the IMF to consult more broadly with all affected

\footnotetext{
${ }^{92}$ See Buria, supra note 19.

${ }^{93}$ Woods, Ngaire and Lombardi, Domenico, Uneven patterns of Governance: How Developing Countries Are Represented in the IMF, 13 REV. INT’L POL. ECON. 480, 495. (2006).
} 
parties in its member states and not to limit its dealings with the member states to their Central Banks and Ministries of Finance.

\section{2) Actions to Alter the Structure and Functions of the IMF to Recognize the Changing Responsibility of the IMF:}

a) Implement the findings of the independent review commission that investigated the division of responsibilities between the IMF and the World Bank.

\section{$\underline{\text { VII. Conclusion }}$}

The IMF is suffering from serious structural distortions that have slowly developed since the Second Amendment to the Articles of Agreement. These problems create a substantial barrier to the effective functioning of the IMF. They can only be corrected through a broad ranging reform program that will overhaul the structure and operating principles of the IMF. Without undertaking this reform program, it is unclear if the IMF will ever be able to effectively make any useful contributions to solving the complex problems of poverty, inequality and inadequate governance which plague developing countries today. 